J. Product. \& Dev., 21(1): 67- 96(2016)

\title{
INVESTIGATING THE EFFECT OF SOME ELICITORS ON BROWN ROT DISEASE AND TUBER YIELD OF POTATO (Solanum tuberosum L.)
}

\author{
A. S. Ezzat * and Z. Moussa** \\ *Vegetable Res. Dept., Hort. Res. Inst., Agric. Res. Center, Giza Egypt. \\ ***Bacterial Disease Res. Dep., Plant Pathology Res. Inst., Agric. Res. Center, Egypt.
}

\section{ABSTRACT}

Brown rot of potato is a worldwide disease that causes huge agricultural and economical losses. Using synthetic chemicals like antimicrobial pesticide may have adverse effects on consumers and on the environment. The recent trend of control plant disease is the application of eco-friendly tools to control disease. In the present investigation, and this study streptomycin, Pleurotus columbinus spent wheat straw (PCSWS), wheat straw (WS), three bacterial species (Bacillus subtillus, B. polymyxa and Pseudomonas fluorescens), plant essential oils of anethole, mustard, caraway and neem were tested to control brown rot disease of potato cv. Spunta in Baramoon Research Station, Dakahlia Governorate, Egypt under field conditions, during the two winter seasons of 2013/14 and 2014/15.

The vegetative growth parameters, tuber yield, tuber grading, tuber dry matter, specific gravity and infected tubers were investigated. PCSWS led to significant increase in all studied criteria, compared to check or other treatments. Furthermore, PCSWS or caraway oil gave the best results in reduction of infected tubers in vitro. The direct antibacterial effect of studied treatments against the causal pathogen of brown rot of potato; Ralstonia solanacerum. Only streptomycin, anethole and caraway oil affected the growth of $R$. solanacearum. Pots experiment was carried out to study the ability of the tested treatments to induce systemic resistance (ISR).

Conclusively, Bacillus subtillus, caraway and neem oils significantly increased the production of total phenols, polyphenol oxidase and peroxidase, respectively, which enhanced potato plant health, increased chlorophylls and plant height as well as, decreased disease rating that increased tuber weight after 70 days of planting.

Key words: Potato, production, brown rot, essential oils, organic residues, streptomycin. 


\section{INTRODUCTION}

Harmful bacteria or pathogens can affect agricultural crops and produce economic losses. Ralstonia solanacearum, a plant pathogen, causes bacterial brown rot in vegetables such as potato, tomato, eggplant and many other plants (Hayward, 1994). This bacterium causes wilt by infecting plants through roots and colonizing stem vascular tissue. Ralstonia solanacearum can overwinter in plant debris or diseased plants, wild hosts, seeds or vegetative propagative organs. As well as the bacteria can survive a long time in water (up to 40 years at $20-25{ }^{\circ} \mathrm{C}$ in pure water) and the bacterial population is reduced in extreme conditions e.g., temperature, $\mathrm{pH}$, salts. Sometimes infected land cannot be used again for susceptible crops for several years (Denny, 2006). Moreover, $R$. solanacearum causes a vascular wilt disease and has been ranked as the second most important bacterial pathogen in potatoes (Yuliar and Toyota, 2015). It is one of the most destructive pathogens identified for induces rapid and fatal wilting symptoms in host plants. The host range is extensively wide, over 200 species; the pathogen is distributed worldwide and induces a destructive economic impact (Kelman, 1998). Direct yield losses by $R$. solanacearum vary widely according to the host, cultivar, climate, soil type, cropping pattern, and strain. For example, yield losses vary from 0 to $91 \%$ in tomato, 33 to $90 \%$ in potato, 10 to $30 \%$ in tobacco, 80 to $100 \%$ in banana, and up to $20 \%$ in the groundnut (Elphinstone, 2005).

Essential oils has an known are antibacterial properties and may provide a solution to tackle brown rot such as caraway oil that contains $\mathrm{S}-(+)-$ carvone. Based on previous studies, it has proven to inhibit bacteria such as E. coli, S. aureus and K. pneumoniae (Seidler-Łożykowska et al., 2013). Neem oil contains different effective phytoconstituents such as alkaloids, glycosides, trepenoids, steroids and tannins act against a wide array of bacteria. It has also been proven to inhibit E. faecalis, $S$. mutans and $S$. aureus (Prabhat and Navneet, 2010). Thyme and eucalyptus oils also suppress on $R$. solanacearum (Hosseinzadeh et al., 2013) and thymol on Xanthomonas axonopodis (Kotan et al., 2007). El-Zemity et al. (2008) showed that growth of Pectobacterium carotovorum on potato was inhibited by thyme oil. Black mustard (Brassica nigra) has an antimicrobial activity, when applied by direct contact into the liquid medium or by exposure in the vapor phase, 
against the growth of Aspergillus niger, Aspergillus ochraceus, or Penicillium citrinum (Beatriz et al., 2015).

Incorporating organic amendments and managing crop residues (type and quality) have a direct impact on plant health and crop productivity. The organic amendments, manures and composts are rich in nitrogen may reduce soil borne diseases by releasing allelochemicals generated during product storage or by subsequent microbial decomposition (Bailey and Lazarovits, 2003).

Plant growth promoting rhizobacteria (PGPR), i.e., Pseudomonas spp., Bacillus spp. enhance plant health and control many plant diseases by many different ways. They can antagonize plant pathogen by inhibiting its growth. PGPR produce phytohormones and encourage induced systemic resistance (ISR). As well as help plant to tolerate abiotic stress as water deficiency (Compant, et al. 2005; Bhattacharyya and Jha, 2012; Yuliar and Toyota 2015 and Noumavo et al., 2016).

Elicitors are biotic or abiotic factors that enhance the resistance of plant against plant pests and increase induced resistance of plants. Use of elicitors to control plant disease is one of the recent trend to control plant disease (Bhattacharyya et al., 2012).

Therefore, this is study aimed to investigate the ability of different bioorigin products to reduce bacterial wilt disease of potato and improve the productivity, explain their abilities as antibacterial in vitro experiment, their ability to act as elicitors encouraging ISR and enhance plant growth in pot experiment.

\section{MATERIALS AND METHODS}

\section{Plant and chemicals}

Potato tubers cultivar (Spunta) was obtained from Nubaria district, Bahaira Government, Egypt. Raw synthetic streptomycin $\left(\left(\mathrm{C}_{21} \mathrm{H}_{39} \mathrm{~N}_{7} \mathrm{O}_{12}\right)_{2} \cdot 3 \mathrm{H}_{2} \mathrm{SO}_{4}\right)$ was used as antibacterial solution (Sigma Chemicals Co., USA), which contains 800 International Units per mg.

Bacteria strains:

Bacterial pathogen: Brown rot local pathogen was isolated and identified as $R$. solanacearum (race 3 biovar 2) virulent strain and provided by the method described with Moussa (2006).

\section{Bacterial bio-agent.}

Three isolates of Bacillus subtilis, Bacillus polymyxa and Pseudomonas fluorescens had PGPR characters and were provided kindly from 
Microbiology Department, Soils, Water and Environment Research Institute, Agricultural Research Center, Giza, Egypt.

Preparation of bacterial pathogen and bacterial bio-agents:

Bacterial pathogen ( $R$. solanacearum) and PGPR bio-agents of $B$. subtilis, B. polymyxa and $P$. fluorescens were inoculated in nutrient growth Glucose Broth (NGB) and incubated in shaker incubator $\left(28{ }^{\circ} \mathrm{C}\right.$ and 120 RPM) for $48 \mathrm{hrs}$. Bacteria were harvested by centrifugation $(10000 \mathrm{rpm} / \mathrm{min}$ for $20 \mathrm{~min}$.), each bacterial species was re-suspend in sterilized tap water and each bacterial suspension was adjusted to $10^{8} \mathrm{cfu} / \mathrm{ml}$ concentration.

$R$. solanacearum bacterial suspension was used for moist soil in pot experiment before $48 \mathrm{hrs}$ of planting. Bacterial bio-agents' suspensions were used to soaking potato seeds for $30 \mathrm{~min}$. before planting in the field and pot experiments.

For preparation the bacterial suspension to in vitro experiments, studied bacteria were seeded on nutrient glucose agar (NGA) slants for $48 \mathrm{hrs}$, harvested, re-suspended in sterilized tap water and adjusted to $10^{8} \mathrm{cfu} / \mathrm{ml}$ concentration.

\section{Organic wastes}

Pleurotus columbinus spent wheat straw (PCSWS) was provided from Mas Mushroom Co., Talkha, Dakahlia governorate, Egypt. Only, wheat straw (WS) powder was prepard from the same Mushroom Co. that used for $P$. columbinus cultivation. PCSWS and WS were grinded well to fine powder. PCSWS and WS were used for coating the tubers before planting.

\section{Essential oils extraction}

Seeds of caraway (Carum carvi L.; Umbelliferae), anise (Pimpinella anisum L.; Apiaceae) and mustard (Brassica nigra L.; Brassicaceae) (200 g seeds from every one) used for oil extraction by hydro-distillation ( 2-3 hr.) according to Chialva et al. (1982) and Charles and Simon (1990). The monoterpene "anethole" fraction used in this study was obtained from anise oil. Essential oils were subjected to GC-MS analysis using a Gas Chromatography (Singh et al., 2005).

Neem (Azadirachta indica A. Juss; Meliaceae) oil was used as a commercial product (Nimbecidine ${ }^{\circledR}$, T. Stanes \& Co. Ltd.) extracted from the seeds of the neem plant. The product component contains azadirachtin (neem bitter), $3.5 \%$, neem oil $75 \%$, emulsifier $10 \%$, diluent $9 \%$ and other limonoids including meliantriol, salanin, nimbin and a host of other terpinoids in the ratio as it occurs naturally in neem. 


\section{Application technique}

The different solutions concentration were prepared as follow; Streptomycin solution $(2.5 \mathrm{~g} / \mathrm{L})$; anethole $(5 \mathrm{ml} / \mathrm{L})$; mustard oil $(5 \mathrm{ml} / \mathrm{L})$ and caraway oil $(2.5 \mathrm{ml} / \mathrm{L})$. Few drops of tween 80 were added to emulsify solution. Neem oil concentration was $30 \mathrm{ml} / \mathrm{L}$. All bacterial suspensions were adjusted to $10^{8} \mathrm{cfu} / \mathrm{ml}$. Pleurotus columbinus spent wheat straw (PCSWS) and wheat straw powder (WS) (nearly $50 \mathrm{~g}$ ) mixed with sticker materials $\left(\right.$ super-film $^{\circledR}$ ) and added to seed tuber.

Full potato seed tubers were soaked in streptomycin solution, essential and neem oils, anethole emulsions and bacterial suspension for 30 minutes for each individual treatment or completely coated by PCSWS and WS fine powder before planting.

\section{Test of sprout inhibition}

Each studied treatment was used in experiment to know the possibility of inhibition. Streptomycin, anethole, neem oil, mustard and caraway oils were used in 5 concentrations $(0.25,0.50,1,2$ and $3 \mathrm{~g} / 1$ for streptomycin and $\% \mathrm{v} / \mathrm{v}$ for others). While, the tested bacteria (Bacillus subtilis, Bacillus polymyxa and Pseudomonas fluorescens) were used in one concentration $10^{8}$ cfu / ml bacterial suspension. Three potato tubers were immersed in each solution or suspension for 30 minutes. In addition, PCSWS and WS powders were moistened by little water and used to cover potato seed tubers (three replicates for each treatment). Immersing potato seeds in tap water for 30 minutes used as a control treatment. Potato tubers were examined after two weeks to see the effect of sprout in potato pieces.

\section{Detection of presence of $R$. solanacearum in invitro:}

The field of this study had history of infection of brown rot disease of potato. To confirm the presence of $R$. solanacearum in this field, soil samples were taken from different locations. Tenfold serial dilutions were applied for the composite sample of this soil suspension of the soil mixture of different samples and $0.1 \mathrm{ml}$ of dilutions $10^{-3}$ and $10^{-4}$ dilution was spotted and spread on the surface of solidified plate SMSA medium (Elphinstone et al., 1996). Three replicates were prepared. Approximately after 2-5 days of incubation, number of colonies of $R$. solanacearum was recorded for each replicate and the mean value of $\mathrm{cfu} / \mathrm{gm}$ was calculated. 


\section{Field experiment:}

The experiments were conducted at Baramoon Research Station, Dakahlia, Egypt ( $+7 \mathrm{~m}$ altitude, $30^{\circ} 11^{-}$latitude and $28^{\circ} 26^{-}$longitude), during winter seasons of 2013/2014 and 2014/2015. The soil is a clay loam in texture, with $1.2 \%$ organic matter and $\mathrm{pH} 7.9$. Extractable soil $\mathrm{P}$ and $\mathrm{K}$ levels in the plots used in this 2-yr trial were in the range of 12.2 to $13.6 \mathrm{mg} / \mathrm{kg}$ for $\mathrm{P}$ and 290 to $302 \mathrm{mg} / \mathrm{kg}$ for K. Local climate is Mediterranean type, warm and rainy during the winter season. Temperature range was between 5.5 and $30.2{ }^{\circ} \mathrm{C}$. The weight of tubers were within range of 40 to $60 \mathrm{~g}$, sown was on October $15^{\text {th }}$ in both growing seasons.

The plot area was $11.25 \mathrm{~m}^{2}$. It contains three lines with $5 \mathrm{~m}$ in long and $0.75 \mathrm{~m}$ distance among lines. Calcium superphosphate was mixed within the upper soil layer $(0-25 \mathrm{~cm})$ before planting. All treatments were planted in hills $25 \mathrm{~cm}$ apart. After planting, the soil can be ridged up around the plants, either along rows or around individual plants as hills. This can also be done when plants are around $20 \mathrm{~cm}$ tall, as part manual wedding operations. Earthing up the soil around the base of stems favors tuber formation. Nitrogen (ammonium nitrate $33.5 \% \mathrm{~N}$ ), phosphorus (mono-superphosphate $15.5 \% \quad \mathrm{P}_{2} \mathrm{O}_{5}$ ) and potassium (potassium sulphate $48 \% \mathrm{~K}_{2} \mathrm{O}$ ) were applied in the rate of 180, 75 and $96 \mathrm{~kg} /$ fed., respectively. Nitrogen fertilizer was added at three equal doses, i.e., after emergence, and with $2^{\text {nd }}$ and $3^{\text {rd }}$ irrigation, respectively. Potassium was added at two times with two equal portions with the second and third additions of $\mathrm{N}$-fertilizer. The other agricultural practices were carried out according to the recommendation of Ministry of Agriculture. A complete randomized blocks design with three replicates was used and the treatments were allocated in their replicates randomly.

\section{Vegetative growth, yield and yield components:}

A random sample of three plants from each experimental plot was taken at tuberization stage (60 days after planting) to determine plant height $(\mathrm{cm})$, leaf area $\left(\mathrm{m}^{2}\right)$ and dry weight $(\mathrm{g})$. At harvest time, 110 days after planting, the total tuber yield ( ton/fed.) and grading the tubers into three size categories based on tubers diameters $(<30,30: 60$ and $>60 \mathrm{~mm})$ were recorded.

Increase $\%$ in total potato tuber yield was calculated according to the following equations:

(Total tuber yield of treatment - Total tuber yield of control)

Increase $\%$ in total potato tuber yield $=$---------------------- 


\section{Tuber quality}

The quality of the harvested tuber for each treatment was determined. The percentage of tuber dry matter was calculated by drying 100 grams of fresh tubers in oven at $70{ }^{\circ} \mathrm{C}$ tills a constant weight. Starch was determined according to the methods described by AOAC, 1990. A sample of 20 tubers randomly selected from each plot was determined for specific gravity using the weight-in-air/weight-in-water method.

\section{Storage of potato tubers after harvest time}

In order to show the latent infection of brown rot disease of potato, after harvest time, the tubers $(5 \mathrm{~kg})$ for each experimental unit were stored at room temperature $\left(24-28{ }^{\circ} \mathrm{C}\right)$ and kept under thick layers of rice straw $(50 \mathrm{~cm}$ thickness) for 30 days (curing). The tubers were examined for the presence of the studied disease at the end of the storage period ( $4^{\text {th }}$ of March). The percentage of infected tubers was calculated for each treatment after storage period and mean value of percentage of total infected tubers was calculated. Decrease \% in infected tuber was calculated according to the following equation:

(Infected tuber \% of control - Infected tuber \% of treatment)

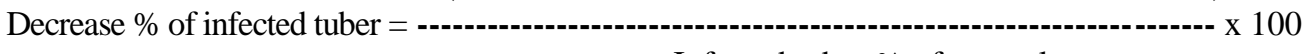

Infected tuber $\%$ of control

Antibacterial activity against $R$. solanacearum:

Disk diffusion method: Molten semi-solid nutrient glucose agar (NGA) medium (3 ml) was inoculated with $0.1 \mathrm{ml}$ of $R$. solanacearum $48 \mathrm{hr}$. old $\left(10^{8} \mathrm{cfu} / \mathrm{ml}\right)$ suspension, shacked well and pour onto previously solidified NGA medium petri dishes. Paper disks of $5 \mathrm{~mm}$ diameter (Watman No. 1 filter paper) were immersed in the three tested oils, anethole emulsions and $0.025 \%(\mathrm{w} / \mathrm{v})$ streptomycin solution, then left to dry. Paper discs were immersed in sterile distilled water and dipped in powders of PCSWS and WS. Immersing paper discs in sterile distilled water only was applied as control treatment. One disc was placed onto the middle of each previously prepared inoculated plates. Three replicates were used for each treatment. The plates were incubated at $28{ }^{\circ} \mathrm{C}$ for 48 hrs. (Kalemba and Kunicka, 2003). Each plate was examined. The inhibitory effect of each treatment against $R$. solanacearum was measured by recording the inhibition zone diameter (mm) around paper disk.

\section{Determination of minimal inhibitory concentrations (MICs):}

The minimum inhibitory concentrations (MICs) for the studied essential oils and streptomycin were determined by using agar dilution method 
(Hammer et al., 1999) with some modifications. A final concentration of $0.5 \%(\mathrm{v} / \mathrm{v})$ Tween-80 was incorporated into the agar after autoclaving to enhance oil solubility. A series of dilutions of each treatment, (4, 3, 2, 1, 0.5 and $0.25 \%(\mathrm{v} / \mathrm{v})$, was prepared in molten NGA medium with $0.5 \%(\mathrm{v} / \mathrm{v})$ Tween-80. Plates were dried prior to inoculation with $R$. solanacearum. Inoculation was carried out with streaking $R$. solanacearum by sterilized loop from liquid culture onto the prepared plates. Plates of NGA medium, with $0.5 \%$ (v/v) Tween-80 and without any treatment, was used as a growth control. Inoculated plates were incubated at $28{ }^{\circ} \mathrm{C}$ for $48 \mathrm{hrs}$. The MICs were determined as the lowest concentration of the treatment that completely inhibits the growth of bacteria on the agar plate.

\section{Investigation of antagonistic activity of studied bacteria against $R$. solanacearum:}

The methods described by Waksman (1967) with some modifications were used for determination of antagonistic activity of studied bacteria against brown rot disease.

\section{Double layer method:}

Only one loop of each tested antagonistic bacteria species cultures $\left(10^{8}\right.$ $\mathrm{cfu} / \mathrm{ml}$ ) was seeded in the middle of solidified NGA plates as straight line. These plates were incubated at $28^{\circ} \mathrm{C}$ for 2 days. A second layer of semi-solid agar containing $48 \mathrm{hrs}$. old of virulent culture of $R$. solanacearum $(0.1 \mathrm{ml}$ of $108 \mathrm{cfu} / \mathrm{ml}$ bacterial suspension added into $3 \mathrm{ml}$ molten semi-solid NGA vortexed well, poured for each plate) rotated gently by palm to homogenous distribution onto the plate. Three replicates were used for each studied bacterial species. The plates were incubated at $28^{\circ} \mathrm{C}$ for $48 \mathrm{hrs}$. The presence of clear zone around the straight line of tested antagonistic bacterial species indicates the positive antagonistic activity against $R$. solanacearum. The diameters of clear zones (if present) were measured.

\section{Disk agar method}

Each tested bacterial species was cultured by adding $1 \mathrm{ml}$ of $108 \mathrm{cfu} /$ $\mathrm{ml}$ bacterial culture on each $9 \mathrm{ml}$ petri dish, pour $15 \mathrm{ml}$ molten NGA medium and incubated at $28{ }^{\circ} \mathrm{C}$ for 2 days. Disks of each tested bacterial species of diameter $9 \mathrm{~mm}$ were prepared by sterilized cork borers. The bacterial disks were appropriately placed onto the center of solidified NGA plates freshly seeded with $R$. solanacearum. Three replicates were prepared for each treatment. The plates were incubated at $28{ }^{\circ} \mathrm{C}$ for $48 \mathrm{hrs}$. The inhibition zones were measured (in millimeters). 


\section{Pots experiment}

This experiment was carried out at the Farm of Fac. Agric., Mansoura Univ., Egypt during the period of $19^{\text {th }}$ November 2015 to $30^{\text {th }}$ January 2016 at open air. The plastic sacks of $35 \mathrm{~cm}$ diameter were filled with $20 \mathrm{~kg}$ nonsterilized soil. This soil was mixture of clay and sand 1:1 (w: w). Soils of each pot were soaked with water and left to dry for 72 hours. The sacks were infested by $R$. solanacearum (about 106 CFF O.D. 0.1 at $600 \mathrm{~nm}$ ); $100 \mathrm{ml}$ for each sack. The sacks were left for about 48 hours before sowing.

The studied treatments were prepared as mentioned before in field experiment. Two potato seed tubers were planted in each sack (pot). After emergency, one plant was harvested after 40 days for estimation plant growth hormones and other plant was harvested after 70 days for estimation of chlorophylls, plant length, foliage fresh and dry weights and tuber number and its weight. Three replicates were prepared for each treatment. This experiment was designed according to complete randomized design.

\section{Estimation of growth regulator hormones of the three bacterial bio-agent:}

Bacterial suspensions of the three biocontrol agent (B. subtilis, B. polymyxa and $P$. fluorescens) grown in nutrient glucose broth (NGB) of 48 hrs., old were adjusted to $10^{8}$ concentrations. These suspensions were centrifuged $(10000 \mathrm{rpm} / \mathrm{min}$ for 20 mints.). Supernatants were sterilized by millipore filters $(0.450 \mu \mathrm{m})$.

Sterilized filtrates of bioagent bacterial suspensions were used in the biochemical analysis. All biochemical analysis was performed in Mansoura Unit of Soils, Water and Environment, Agricultural Research Center, Egypt.

Determination of indole acetic acid (IAA) was carried out according to the procedure of Glickmann and Dessaux (1995), gibberellic acid $\left(\mathrm{GA}_{3}\right)$ by the procedure of Holbrook et al., (1961) and cytokinin by the procedure reported by Hoyerováa et al. (2006).

\section{Disease assessment and biochemical testes under greenhouse conditions:}

After 40 days from sowing, the total phenol content was determined using folin ciocalteau reagent according to the method described by Maliak and Singh (1980), whereas, extraction and assay of polyphenoloxidase (PPO) and peroxidase (POD) were carried out according to the methods described by Maria et al. (1981) and Maxwell and Bateman (1967), respectively. Estimation of chlorophylls was done according to Nagata and Yamashita (1992) at 70 days from planting. 
Disease rating: Wilt symptoms severity were recorded daily according to the scale of Kempe and Sequeira (1983) where, $(0=$ no symptoms, $1=$ up to $25 \%$ wilt, $2=26-50 \%$ wilt, $3=51-75 \%$ wilt, $4=76-99 \%$ of the foliage wilted and $5=$ dead plants. Each replicate was examined and disease ratting (severity) was recorded. Mean value for each treatment was calculated.

\section{Statistical analysis:}

Data were analyzed with the statistical analysis software CoStat (version 6.4), by the one-way randomized completely blocks design(RCBD). Duncan's multiple range test (Duncan, 1955) was used to compare the means at probability $(P)$ level 0.05 .

\section{RESULTS AND DISCUSSION}

\section{Sprouting}

Immersing potato seed tubers in tap water (control), or $10^{8}$ suspension of $B$. subtilis, B. polymyxa and P. fluorescens did not inhibit sprout of potato pieces. Moreover, covering potato pieces with Pleurotus columbinus spent wheat straw powder and wheat straw powder did not any inhibition on potato sprout. In addition, all five tested concentrations of anethole and neem oil did not affect potato sprout (Table 1). On the contrast, streptomycin, mustard oil and caraway oil had effects on potato sprouting. Streptomycin concentrations $0.25,0.5$ and $1 \mathrm{~g}$ did not refection any inhibition. While, streptomycin at $2 \mathrm{~g}$ inhibited $33 \%$ of potato pieces, at $3 \mathrm{~g}$ concentration, $100 \%$ inhibit of potato infection were observed. Furthermore, only the concentration 0.25 at $\%$ of mustard and caraway oil did not inhibit potato sprout, while other tested concentrations of the two oil affected the potato sprout. The two concentrations, 0.25 and $0.5 \%$ of mustard oil inhibited $33 \%$ of potato pieces, while, the two concentrations, 2 and $3 \%$ inhibited $66.67 \%$ of potato pieces. As well as, the concentration of $0.5 \%$ of caraway oil inhibited $33 \%$ of potato pieces. The concentration of $1 \%$ of caraway oil inhabited $66.67 \%$ of potato pieces. While, the two concentrations, 2 and $3 \%$ of caraway oil completely inhabited the potato seeds (100\%) as shown in Table 1. 
Table 1: Sprouting of potato seed tubers ( $c v$. Spunta) as affected by treatments.

\begin{tabular}{|c|c|c|}
\hline Treatments & $\begin{array}{c}\text { Studied } \\
\text { concentration }\end{array}$ & $\begin{array}{c}\text { Sprouting inhibition } \\
(\%)\end{array}$ \\
\hline 1. Control & - & 0 \\
\hline \multirow{5}{*}{ 2. Streptomycin } & $0.25 \mathrm{~g} / 1$ & 0 \\
\hline & $0.50 \mathrm{~g} / 1$ & 0 \\
\hline & $1.00 \mathrm{~g} / 1$ & 0 \\
\hline & $2.00 \mathrm{~g} / 1$ & 33.33 \\
\hline & $3.00 \mathrm{~g} / 1$ & 100 \\
\hline 3. Pleurotus columbinus spent wheat straw & Powdering & 0 \\
\hline 4. Wheat straw & Powdering & 0 \\
\hline 5. Bacillus subtilis & $10^{8} \mathrm{CFU} / \mathrm{ml}$ & 0 \\
\hline 6. Bacillus polymyxa & $10^{8} \mathrm{CFU} / \mathrm{ml}$ & 0 \\
\hline 7. Pseudomonas fluorescens & $10^{8} \mathrm{CFU} / \mathrm{ml}$ & 0 \\
\hline \multirow{5}{*}{ 8. Anethole } & $0.25 \%$ & 0 \\
\hline & $0.50 \%$ & 0 \\
\hline & $1.00 \%$ & 0 \\
\hline & $2.00 \%$ & 0 \\
\hline & $3.00 \%$ & 0 \\
\hline \multirow{5}{*}{ 9. Neem oil } & $0.25 \%$ & 0 \\
\hline & $0.50 \%$ & 0 \\
\hline & $1.00 \%$ & 0 \\
\hline & $2.00 \%$ & 0 \\
\hline & $3.00 \%$ & 0 \\
\hline \multirow{5}{*}{ 10. Mustard oil } & $0.25 \%$ & 0 \\
\hline & $0.50 \%$ & 33.33 \\
\hline & $1.00 \%$ & 33.33 \\
\hline & $2.00 \%$ & 66.67 \\
\hline & $3.00 \%$ & 66.67 \\
\hline \multirow{5}{*}{ 11. Caraway oil } & $0.25 \%$ & 0 \\
\hline & $0.50 \%$ & 33.33 \\
\hline & $1.00 \%$ & 66.67 \\
\hline & $2.00 \%$ & 100 \\
\hline & $3.00 \%$ & 100 \\
\hline
\end{tabular}

Studying the effect of studied treatments on potato sprout before the field experiment to be sure that the used concentrations of these treatments did not inhibit potato sprout and did not inhibit potato seedling growth. The results indicated that $10^{8} \mathrm{CFU} / \mathrm{ml}$ bacterial suspension of $B$. subtilis, $B$. polymyxa and $P$. fluorescens did not suppress potato sprout. In addition, Pleurotus columbinus spent wheat straw and wheat straw did not inhibit 
potato sprout. Anethole and Neem oil of concentration $3 \%$ or under this concentration did not inhibit potato sprout. Potato sprout inhabited completely by streptomycin concentration 3\% and caraway oil (2 and 3\%). These results had the agreement of Sonli et al. (2010), they reported that potato sprout suppressed by essential oils.

\section{Field experiment}

Although, the field of this experiment had history of bacterial wilt disease of potato, the presence of $R$. solanacearum was confirmed by cultivation soil extract on SMSA medium. The mean number of colonies of $R$. solanacearum in the soil was $2 \times 10^{5} \mathrm{cfu} / \mathrm{gm}$ soil. So, this field was surely naturally infested by $R$. solanacearum.

All tested treatments gave a significant effects on vegetative growth parameters, in comparison with the control. Coating potato seeds with Pleurotus columbinus spent wheat straw (PCSWS) led to a significant effect on plant height, leaf area and dry weights per plant in comparison with other treatments (Table 2). This is true in both growing seasons. Caraway oil and streptomycin came the second and third treatments in all studied criteria.

Table 2: Vegetative growth characters of potato as affected by tested treatments to control brown rot disease in 2013/14 and 2014/15 seasons.

\begin{tabular}{|l|c|c|c|c|c|c|}
\hline \multirow{2}{*}{ Treatments } & \multicolumn{2}{|c|}{$\begin{array}{c}\text { Plant height } \\
\text { (cm) }\end{array}$} & \multicolumn{2}{c|}{$\begin{array}{c}\text { Leaf area / plant } \\
\left(\mathbf{m}^{\mathbf{2}}\right)\end{array}$} & \multicolumn{2}{c|}{$\begin{array}{c}\text { Dry weight of foliage } \\
\text { / plant (g) }\end{array}$} \\
\cline { 2 - 7 } & $\mathbf{2 0 1 3 / 1 4}$ & $\mathbf{2 0 1 4 / 1 5}$ & $\mathbf{2 0 1 3 / 1 4}$ & $\mathbf{2 0 1 4 / 1 5}$ & $\mathbf{2 0 1 3 / 1 4}$ & $\mathbf{2 0 1 4 / 1 5}$ \\
\hline 1. Control & $47.00 \mathrm{~d}$ & $46.00 \mathrm{~d}$ & $0.41 \mathrm{e}$ & $0.43 \mathrm{~d}$ & $27.88 \mathrm{e}$ & $26.00 \mathrm{f}$ \\
\hline 2. Streptomycin & $58.67 \mathrm{ab}$ & $56.33 \mathrm{ab}$ & $0.50 \mathrm{~b}$ & $0.51 \mathrm{~b}$ & $34.12 \mathrm{ab}$ & $33.76 \mathrm{ab}$ \\
\hline $\begin{array}{l}\text { 3. Pleurotus columbinus spent } \\
\text { wheat straw }\end{array}$ & $60.67 \mathrm{a}$ & $58.00 \mathrm{a}$ & $0.54 \mathrm{a}$ & $0.54 \mathrm{a}$ & $36.76 \mathrm{a}$ & $34.84 \mathrm{a}$ \\
\hline 4. Wheat straw & $52.00 \mathrm{c}$ & $52.33 \mathrm{bc}$ & $0.42 \mathrm{e}$ & $0.39 \mathrm{e}$ & $28.55 \mathrm{de}$ & $27.16 \mathrm{ef}$ \\
\hline 5. Bacillus subtilis & $52.33 \mathrm{c}$ & $54.67 \mathrm{abc}$ & $0.42 \mathrm{e}$ & $0.43 \mathrm{~d}$ & $28.42 \mathrm{de}$ & $26.76 \mathrm{ef}$ \\
\hline 6. Bacillus polymyxa & $54.67 \mathrm{bc}$ & $54.00 \mathrm{abc}$ & $0.43 \mathrm{e}$ & $0.42 \mathrm{~d}$ & $29.18 \mathrm{de}$ & $28.70 \mathrm{def}$ \\
\hline 7. Pseudomonas fluorescens & $56.00 \mathrm{bc}$ & $57.00 \mathrm{a}$ & $0.46 \mathrm{~d}$ & $0.48 \mathrm{c}$ & $31.27 \mathrm{bcd}$ & $32.73 \mathrm{abc}$ \\
\hline 8. Anethole & $54.67 \mathrm{bc}$ & $55.00 \mathrm{abc}$ & $0.43 \mathrm{e}$ & $0.42 \mathrm{~d}$ & $28.95 \mathrm{de}$ & $29.15 \mathrm{de}$ \\
\hline 9. Neem oil & $52.33 \mathrm{c}$ & $51.33 \mathrm{c}$ & $0.49 \mathrm{bc}$ & $0.49 \mathrm{c}$ & $33.12 \mathrm{bc}$ & $32.00 \mathrm{bc}$ \\
\hline 10. Mustard oil & $57.33 \mathrm{ab}$ & $56.00 \mathrm{ab}$ & $0.45 \mathrm{~d}$ & $0.47 \mathrm{c}$ & $30.52 \mathrm{cde}$ & $27.30 \mathrm{ef}$ \\
\hline 11. Caraway oil & $58.00 \mathrm{ab}$ & $56.33 \mathrm{ab}$ & $0.48 \mathrm{c}$ & $0.48 \mathrm{c}$ & $31.00 \mathrm{~b}-\mathrm{e}$ & $30.80 \mathrm{~cd}$ \\
\hline
\end{tabular}

Means followed by the same letter (s) within each column do not significantly differ using Duncan's Multiple Range Test at the level of $5 \%$. 
Organic amendments to soil have direct impacts on plant health and crop productivity. They are advantageous because they improve the physical, chemical, and biological properties of soil, which can have positive effects on plant growth (Bailey and Lazarovits, 2003). The degradation of organic matter in soil can directly affect the viability and survival of a pathogen by restricting available nutrients and releasing natural chemical substances with varying inhibitory properties (Bailey and Lazarovits, 2003). Moreover concluded that carbon released during the degradation of organic matter contributes in increasing soil microbial activity and thereby enhances the likelihood of competition effects in the soil (Bailey and Lazarovits, 2003). Organic amendments to soil have been shown to stimulate the activities of microorganisms that are antagonistic to pathogens (Akhtar and Malik, 2000). In addition, organic amendments often contain biologically-active molecules such as vitamins, growth regulators, and toxins, which can affect soil microorganisms and enhance plant growth. Recently, Youssef and Tartoura (2013) reported that plant resistance against the bacterial wilt pathogen was enhanced through the augmented activities of ascorbate peroxidase, monodehydro ascorbate reductase, dehydroascorbate reductase, and glutathione reductase following the application of organic residues.

The three tested PGPR (B. subtilis, B. polymyxa and $P$. fluorescence) increased significantly vegetable growth characters more than control treatment. This may be due to they act as bio-fertilizer by phosphate solubilization, siderophores production, exopolysaccharides production and/or biofixation of atmosphere nitrogen (Noumavo et al., 2016).

The three tested essential oils (mustard, caraway and anethole) and neem enhanced vegetative growth characters of potato plant characters in the field experiment. These results had conformity of Momol et al. (2005) who used essential oil in field experiment to control bacterial wilt of tomato.

All tested treatments exhibited significant differences $(\mathrm{P} \leq 0.05)$ in total tuber yield (ton/ fed.) in the first season (Table 3). PCSWS gave the highest yields (14.5 and 13.6 ton/fed.) in both seasons, respectively, followed by caraway oil treatment, Pseudomonas fluorescens and streptomycin while the control had the least. The percentage of increase of PCSWS over the control reached 49.51 and $50.88 \%$ and 46.81 and $48.23 \%$ for caraway oil, in both seasons.

The proportion of grade-sized tubers 30: $60 \mathrm{~mm}$ and over $60 \mathrm{~mm}$ were significant in both seasons and it took the manner of total tuber yield as previously mentioned. Science, total yield increases were due to primarily the 
increase in tuber size in larger and medium grades and decrease of the small grades. In this respect, the treatment of PCSWS increased significantly weights of large $(>60 \mathrm{~mm})$ and medium tubers $(30: 60 \mathrm{~mm})$ and significantly decreased small tuber weight $(<30 \mathrm{~mm})$, in both seasons, respectively. There were no significant differences $(\mathrm{P} \leq 0.05)$ among tested elicitors for tuber weight $<30 \mathrm{~mm}$, in both seasons. There are no differences between the tested essential oils on medium tubers weight in both growing seasons.

These results may be due to that PCSWS contains antibacterial compound(s) which was soluble in water. These results were confirmed by the results of Tan and Wahab (1997). They reported that Pleurotus sajor-caju grown on cotton waste produces relatively low levels of three components namely cellobiohydrolase, CMCase and $\beta$-glucosidase. Also, VelázquezCedeňo et al. (2002) indicated that the two basidomycetes Pleurotus ostreatus and $P$. pulmonarius had the ability to produce some extracellular lignocellulytic enzymes.

At around tuberization stage, the plants' water demand is very high and they wilt rapidly due to the blockage of the xylem tissue by the bacterial mass. In addition, due to high transpiration rates, the plants take up a lot of water (together with bacteria in the soil water) and hence wilt rapidly. Total tuber yield was higher in the first season than the second. This is most likely due to lower temperatures experienced during the first season compared to the second season (data not shown). Disease expression in the field is favored by high temperatures (EPPO, 2004).

There were a significant differences in potato tuber quality parameters. Application of PCSWS significantly increased tuber dry matter in both seasons, starch and specific gravity of tubers ( $1^{\text {st }}$ season, only) and significantly decreased infected tubers (both seasons), in comparison with other treatments (Table 4).

These increases in dry matter, starch and specific gravity may be attributed to PCSWS had antimicrobial agents against pathogenic bacteria and fungi and this of course is reflected in the quality of tubers (Rai and Tidke, 2005). These results are confirmed with those of Okamoto et al. (2002) and Velázquez-Cedeňo et al., (2002). Furthermore, PCSWS may directly or indirectly suppress disease with enhancing production of decomposed products by antagonistic microbial population or stimulation the production of lytic enzymes involved in the degradation of plant pathogens (Gamliel et al., 2000). 
EZZAT \& MOUSSA 
PGPR significantly increased tuber yield and quality. This may be due to phytostimulation by production of auxins, cytokinins, gibberellins, which regulate the hormones system in plant and increasing plant growth ( Table 2), tuber yield (Table 3) and then increasing tuber quality (Noumavo et al., 2016). Tested essential oils and anethole increase tuber yield and quality. The authors suggest that may be due to their elicitor effect on potato plant enhancing production of some growth hormones.

The aggressiveness of the pathogen is affected mainly by temperature and moisture; high temperature and high soil moisture during the first half stage of plant age promote survival, reproduction, infectivity, and spread of the bacterium, and hence disease development (Martin and French, 1985). This high soil bacterial population combined with the vigorous vegetative plant growth probably led to the rapid increase in the disease incidence (infected tubers) in the field (Table 4).

Data in (Table, 4) illustrated that, PCSWS, Pseudomonas fluorescens and caraway oil had a significant reduction in percentage of tubers infected (Table 4). The possible mechanisms of action of the plant residues are mainly considered to be antimicrobial activities, followed by the indirect suppression of the pathogen through improved physical, chemical, and biological soil properties that reflected on growth and yield (Cardoso et al., 2006). Respecting the role of antimicrobial compounds, the antimicrobial compounds from Tagetes patula that suppressed $R$. solanacearum in an in vitro experiment were identified as 5-(3-buten-1-ynyl)-2,2'-bithienyl (BBT) and 5-(4-acetoxy-1-butynyl)-2,2'-bithienyl (BBTOAc) (Terblanche and Villiers, 1998). Lansiumamide B isolated from the seeds of Clausena lansium suppressed tobacco bacterial wilt more than an antibiotic streptomycin when applied at a density of $100 \mathrm{mg} / \mathrm{kg}$ (Li et al., 2014).

The three-tested PGPR decreased tubers infected \% may be due to their antibacterial activities and/or increasing ISR activity of plant (Battacharyya and Jha, 2012). Suppression mechanisms are typically attributed to the antibacterial metabolites produced by PGPR or those present in natural products; however, the number of studies related to host resistance to the pathogen is increasing. Enhanced/modified soil microbial communities are also indirectly involved in disease suppression (Yuliar and Toyota, 2015). In this respect, Pseudomonas fluorescens had a significant reduction of infected tubers percent. 
The three essential oils and neem decreased infected tubers. Caraway oils gave the best results $(0.00 \%)$. In this respect, Alamshahi and Nezhad (2015) reported that thyme essential oil caused significant reduction in soft rot and bacterial wilt incidence on potato by 41 and $44 \%$, respectively. The same treatment on tomato caused $50 \%$ reduction of wilt compared with the control sample. Under field conditions, suppression of bacterial wilt $(R$. solanacearum) was observed by treating with thymol oil (Ji et al., 2007). Also, this finding had confidence of Momol et al. (2005), who showed that essential oils were effective tools to fight bacterial wilt disease in field experiment. This may be due to their antagonistic effect against $R$. solanacerum and/ or their role as an elicitor enhancing ISR. In addition, this may be due to their antagonistic effect against other soil microflora, so, they change soil microbial community that indirect inhibited $R$. solanacearum and reduced the disease severity, hence decrease infected tubers. Using of antibiotics as streptomycin was a good inhibitor for the bacteria growth compared with pencilin and ampicillin (Khalil, 2008).

\section{Inhibition effects and MICs}

Results in Table 5 show that streptomycin, anethole and caraway oil inhibited the growth of $R$. solanacearum. On contrary, neem and mustard oil did not suppress $R$. solanacearum growth. The minimal inhibition concentration (MIC) of anethole is largest value (3\%). While, MIC of streptomycin is lowest one $(\geq 0.25 \%$ ). The MIC of caraway oil is $0.25 \%$. These results were in the same harmony of Moussa (2006) who found that some essential oil inhibited growth of $R$. solanacearum and others did not inhibit the growth of this bacterium. He also found that anise oil had inhibitory effect against the studied bacterium, then, that confirmed the inhibitory effect of anethole (one component of anise oil) against the same bacterium. Also, Wang et al. (2015) reported that streptomycin suppresses the growth of $R$. solanacearum. In addition, Abo-Elyousr et al. (2014) revealed that caraway oil inhibits the growth of $R$. solanacearum. On the other hand, these results were in contrary with those of Sood and Kumar (2015) who mentioned that neem oil inhibited growth of $R$. solanacearum. Many investigators suggested that difference in the effect of the same essential oil against the same bacterium may be due to the variation of plant part which essential oil was extracted, diversity of plant varieties, variance in soil, in which plant was cultivated and/ or other reasons. This variation may be due difference in studied pathogenic bacterial strains. 
Table 5: Inhibition effects and minimal inhibition concentrations of (MICs) of some tested treatments.

\begin{tabular}{|l|c|c|}
\hline Treatments & $\begin{array}{c}\text { Inhibition zone } \\
(\mathbf{m m})\end{array}$ & $\begin{array}{c}\text { MIC } \\
\mathbf{( \% )}\end{array}$ \\
\hline 1. Control & 0 & N.D. \\
\hline 2. Streptomycin & 1.7 & $\geq 0.25$ \\
\hline 8. Anethole & 1.5 & 3 \\
\hline 9. Neem oil & 0 & N.D. \\
\hline 10. Mustard oil & 0 & N.D. \\
\hline 11. Caraway oil & 1.7 & 0.25 \\
\hline
\end{tabular}

*N.D.: Not detected.

Table (6) was confirmed by Iacobellis et al. (2005) who showed that the caraway essential oil which active against $R$. solanacearum contain carvone, limonene, and trans-dihydrocarvone. Furthermore, Kotan et al. (2013) used carvacrol (pure compound of caraway oil) to control of $R$. solanacearum.

Table 6: The main compounds identified in the methanol extract of tested essential oils by using GC-MS.

\begin{tabular}{|c|c|c|c|c|c|c|}
\hline \multirow[t]{2}{*}{ No. } & \multicolumn{2}{|c|}{ Caraway oil } & \multicolumn{2}{|c|}{ Anise oil } & \multicolumn{2}{|c|}{ Mustard oil } \\
\hline & Compounds & $\begin{array}{c}\text { Concentration } \\
\%\end{array}$ & Compound & $\begin{array}{c}\text { Concentration } \\
\%\end{array}$ & Compounds & $\begin{array}{c}\text { Concentration } \\
\%\end{array}$ \\
\hline 1 & Myrcene & 0.48 & Anethole & 80 & $\begin{array}{c}\text { Ally } \\
\text { isothiocyanate }\end{array}$ & 94 \\
\hline 2 & Limonene & 15.50 & Estragole & 10 & $\begin{array}{l}\text { 4-hydroxbenzyl } \\
\text { isothiocyanate }\end{array}$ & 6 \\
\hline 3 & $\alpha$-Terpinolene & 0.10 & Fenchone & 7.5 & & \\
\hline 4 & Trans limonene oxide & 2.01 & & & & \\
\hline 5 & Trans dihydro carvone & 0.33 & & & & \\
\hline 6 & Trans carvol & 0.31 & & & & \\
\hline 7 & Estragole & 20.23 & & & & \\
\hline 8 & Carvone & 50.80 & & & & \\
\hline 9 & Perilla alcohol & 1.48 & & & & \\
\hline 10 & Carvacrol & 0.34 & & & & \\
\hline 11 & $\beta$-Caryophyllene & 0.41 & & & & \\
\hline 12 & $\beta$-Pinene & 6.50 & & & & \\
\hline
\end{tabular}

Furthermore, no inhibition zone was recorded with PCSWS and WS when disk diffusion method was applied. These finding mean that PCSWS and WS had no direct antibacterial effect against $R$. solanacerum. El-Fallal and Moussa (2008) showed that water extract of PCSWS and WS had inhibitory effect against $R$. solanacerum. They illustrated that water extract of PCSWS had higher inhibitory effect than that of WS. This difference may be 
due to extracellular enzymes $P$. columbinus, which may play a role in increasing the inhibitory effect against $R$. solanacerum.

In addition, the three tested ( $B$. subtilis, $B$. polymyxa and $P$. fluorescens) bacteria did not inhibit the growth of $R$. solanacearum where there is no inhibition zone was recorded when double layer and disk agar method were applied. These results are contrariwise those of Kheirandish and Harighi (2015) who found that different strains of P. fluorescens antagonized the growth of $R$. solanacerum. Also, these results are on the contrary of those of Kwon and Kim (2014) who demonstrated that B. subtilis suppressed the growth of $R$. solanacerum. In addition, Nath et al. (2016) had counteractive results of this investigation where they showed that B. subtilis and $P$. fluorescens inhibited the growth of $R$. solanacearum. Some investigators suggest that these counteractive findings of the inhibitory effect of the same bacterial bio-agent against the same bacterial pathogen may be due to the genetic variation of the different strains of bio-agents from different locations and environment and/ or differences in different isolates of the same bacterial pathogen.

\section{Phytohormones secreted by bio-agents}

The three tested of bio-agent bacteria produced indole acetic acid (IAA), gibberellic acid $\left(\mathrm{GA}_{3}\right)$ and cytokinin (Table 7$)$. B. subtilis produced the highest value of IAA $(22.16 \mu \mathrm{g} / \mathrm{ml})$ and cytokine $(13.11 \mu \mathrm{g} / \mathrm{ml})$ and the lowest value of $\mathrm{GA}_{3}(359.22 \mu \mathrm{g} / \mathrm{ml})$. P. fluorescens secreted the largest quantity of $\mathrm{GA}_{3}(588.11 \mu \mathrm{g} / \mathrm{ml})$, lowest value of cytokinin $(8.016 \mu \mathrm{g} / \mathrm{ml})$ and middle value of IAA $(16.98 \mu \mathrm{g} / \mathrm{ml})$. While, $B$. polymyxa have the lowest value of IAA $(18.545 \mu \mathrm{g} / \mathrm{ml})$ and cytokinin $(4.486 \mu \mathrm{g} / \mathrm{ml})$ and middle one of $\mathrm{GA}_{3}(4.93 .6 \mu \mathrm{g} / \mathrm{ml})$. These results have confirmation of Noumavo et al. (2016) and Wu et al. (2016) they revealed that these bacteria produced these phytohormones and they are plant growth promoting rizobacteria (PGPR).

Table 7: Phytohormones of secreted by the three tested bacteria.

\begin{tabular}{lccc}
\hline Treatments & $\begin{array}{c}\text { Indole acetic acid (IAA) } \\
(\boldsymbol{\mu g} / \mathbf{m l})\end{array}$ & $\begin{array}{c}\mathbf{G A}_{\mathbf{3}} \\
(\boldsymbol{\mu g} / \mathbf{m l})\end{array}$ & $\begin{array}{c}\text { Cytokinin } \\
(\boldsymbol{\mu g} / \mathbf{m l})\end{array}$ \\
\hline 1. Bacillus subtilis & 22.16 & 359.22 & 13.11 \\
2. Bacillus polymyxa & 8.545 & 4936 & 4.486 \\
3. Pseudomonas fluorescens & 16.98 & 588.11 & 8.016 \\
\hline
\end{tabular}




\section{Physiological aspects in pot experiment}

Data in Table (8) illustrate that all tested treatments were effective elicitor where approximately all treatments significantly increased the ability of potato plants in pot experiment to produce total phenols, polyphenol oxidase (PPO) and peroxidase (POD). The best elicitor encouraging production of total phenols was $B$. subtilis, while neem oil and $B$. polymyxa did not increase total phenols. Caraway oil was the first elicitor in increasing PPO, while B. polymyxa was the lowest elicitor significantly increasing it. Neem oil was the number one in increment the production of POD, while PCSWS caused non significantly increase in its production. These findings confirm that the tested elicitors increase induced systemic resistance (ISR). These results had the same harmony of Compant et al. (2005), Bhattacharyya and Jha (2012) and Noumavo et al. (2016), they illustrated that PGPR used as elicitor increasing ISR of plant against pathogens. In addition, PCSWS and WS encouraged the ISR of potato plant. These results confirmed by Gamliel et al., (2000) who showed that organic amendment enhanced the ISR of plants.

Table 8: Physiological characteristics of potato plants at 40 days after planting affected by tested treatments in pots experiment.

\begin{tabular}{|l|c|c|l|}
\hline Treatments & $\begin{array}{c}\text { Total phenol } \\
\text { (mg catechol / } \\
\text { g F.W. })\end{array}$ & $\begin{array}{c}\text { Polyphenol oxidase } \\
\text { (Unit / min. / } \\
\text { g F.W. }\end{array}$ & $\begin{array}{c}\text { Peroxidase } \\
\text { (Unit / min. / } \\
\text { g F.W.) }\end{array}$ \\
\hline 1. Control & $13.48 \mathrm{e}$ & $13.12 \mathrm{e}$ & $0.00 \mathrm{~d}$ \\
\hline 2. Streptomycin & $25.51 \mathrm{c}$ & $13.05 \mathrm{e}$ & $0.00 \mathrm{~d}$ \\
\hline 3. Pleurotus columbinus spent wheat straw & $14.15 \mathrm{e}$ & $25.22 \mathrm{~b}$ & $0.00 \mathrm{~d}$ \\
\hline 4. Wheat straw & $14.48 \mathrm{e}$ & $14.67 \mathrm{de}$ & $20.13 \mathrm{~b}$ \\
\hline 5. Bacillus subtilis & $34.86 \mathrm{a}$ & $12.33 \mathrm{e}$ & $0.00 \mathrm{~d}$ \\
\hline 6. Bacillus polymyxa & $12.82 \mathrm{e}$ & $24.33 \mathrm{~b}$ & $7.67 \mathrm{c}$ \\
\hline 7. Pseudomonas fluorescens & $20.83 \mathrm{~d}$ & $23.33 \mathrm{~b}$ & $19.67 \mathrm{~b}$ \\
\hline 8. Anethole & $32.51 \mathrm{~b}$ & $29.00 \mathrm{a}$ & $0.00 \mathrm{~d}$ \\
\hline 9. Neem oil & $12.82 \mathrm{e}$ & $18.13 \mathrm{c}$ & $44.12 \mathrm{a}$ \\
\hline 10. Mustard oil & $25.50 \mathrm{c}$ & $17.06 \mathrm{~cd}$ & $0.00 \mathrm{~d}$ \\
\hline 11. Caraway oil & $24.50 \mathrm{c}$ & $17.45 \mathrm{~cd}$ & $0.00 \mathrm{~d}$ \\
\hline
\end{tabular}

Means followed by the same letter (s) within each column do not significantly differ using Duncan's Multiple Range Test at the level of $5 \%$.

Results in Table (9) reveal that all tested elicitors enhanced the plant health by increasing the amounts of chlorophylls ( $a, b$ and total). Application of PCSWS and WS had significant effects on these pigments. PCSWS gave the highest value of chlorophyll a $(708 \mathrm{mg} / \mathrm{g})$ and total chlorophyll $(0.891 \mathrm{mg} / \mathrm{g})$ 
Table 9: Chlorophylls of potato plants at 70 days after planting as affected by tested treatments to control brown rot disease in pots experiment.

\begin{tabular}{|l|c|c|c|}
\hline Treatments & $\begin{array}{c}\text { Chlorophyll } \boldsymbol{a} \\
\text { (mg / g F.W.) }\end{array}$ & $\begin{array}{c}\text { Chlorophyll } \boldsymbol{b} \\
\text { (mg / g F.W.) }\end{array}$ & $\begin{array}{c}\text { Total chlorophylls } \\
\text { (mg / g F.W.) }\end{array}$ \\
\hline 1. Control & $0.316 \mathrm{k}$ & $0.070 \mathrm{j}$ & $0.386 \mathrm{~h}$ \\
\hline 2. Streptomycin & $0.433 \mathrm{~h}$ & $0.132 \mathrm{e}$ & $0.565 \mathrm{e}$ \\
\hline 3. Pleurotus columbinus spent wheat straw & $0.708 \mathrm{a}$ & $0.183 \mathrm{~b}$ & $0.891 \mathrm{a}$ \\
\hline 4. Wheat straw & $0.623 \mathrm{~b}$ & $0.215 \mathrm{a}$ & $0.838 \mathrm{~b}$ \\
\hline 5. Bacillus subtilis & $0.521 \mathrm{f}$ & $0.133 \mathrm{e}$ & $0.654 \mathrm{~d}$ \\
\hline 6. Bacillus polymyxa & $0.584 \mathrm{c}$ & $0.126 \mathrm{f}$ & $0.710 \mathrm{c}$ \\
\hline 7. Pseudomonas fluorescens & $0.561 \mathrm{~d}$ & $0.150 \mathrm{~d}$ & $0.711 \mathrm{c}$ \\
\hline 8. Anethole & $0.426 \mathrm{i}$ & $0.175 \mathrm{c}$ & $0.601 \mathrm{f}$ \\
\hline 9. Neem oil & $0.559 \mathrm{e}$ & $0.108 \mathrm{~g}$ & $0.667 \mathrm{~d}$ \\
\hline 10. Mustard oil & $0.443 \mathrm{~g}$ & $0.095 \mathrm{~h}$ & $0.538 \mathrm{f}$ \\
\hline 11. Caraway oil & $0.372 \mathrm{j}$ & $0.088 \mathrm{i}$ & $0.460 \mathrm{~g}$ \\
\hline
\end{tabular}

Means followed by the same letter (s) within each column do not significantly differ using Duncan's Multiple

Range Test at the level of 5\%.

while, the highest value of chlorophyll b $(0.215 \mathrm{mg} / \mathrm{g})$ recorded with WS. This had confirmation of $\mathrm{Wu}$ et al. (2012) and Suzuki et al. (2014) who demonstrated that the application of PGPR led to increment of chlorophyll content of plants. Furthermore, increasing in chlorophyll content due application of WS and PCSWS had the computability of Roy et al. (2015) who illustrated that mushroom substrate enhanced plant health and increased plant chlorophyll content.

Data in Table (10) at 70 days of planting show that, all tested elicitors enhanced plant health and significantly increased the plant height. The longest plant recorded PCSWS and WS. While the shortest plant recorded with $B$. subtilis and B. Polymyxa. In addition, all studied treatments significantly decreased bacterial wilt disease rating. No wilting symptoms were recorded with streptomycin, $P$. fluorescence, neem oil, mustard oil and caraway oil. While, WS, B. subtilis and, B. polymyxa reduced disease rating. Furthermore, all tested factors significantly increased tubers weight/ plant. The best treatment in this factor was PCSWS which increased tuber yield by $53.20 \%$, while the lowest one was B. subtilis that caused increment by $16.04 \%$.

The pot experiment had the same harmony of the field experiment of this investigation. There were differences in results due to differences of environment of pot and field. 
Conclusively, the results of this investigation showed that all tested treatments acted as elicitors encouraging ISR of potato plants. Only three elicitors had a direct antibacterial activity against $R$. solanacearum; streptomycin, anethole and caraway oil, while other treatments had direct antibacterial effect. Therefore, these elicitors were promising tools for ecofriendly management of brown rot disease of potato. The most effective elicitors are PCSWS, caraway oil, $P$. fluorescens and streptomycin. They can be applied before planting for improving yield and its quality, as well as, control brown rot disease of potato.

\section{REFERENCES}

Abo-Elyousr, K.A., Seleim, M.A., Abd-El-Moneem, K.M. and Saead, F.A. (2014). Integrated effect of Glomus mosseae and selected plant oils on the control of bacterial wilt disease of tomato. Crop Prot., 66: 67-71.

Akhtar, M. and Malik, A. (2000). Roles of organic soil amendments and soil organisms in the biological control of plant-parasitic nematodes: A review, Bioresour. Technol., 74:35-47.

Alamshahi, L. and Nezhad, M.H. (2015). Effect of essential oils of five medicinal plants on two microbial diseases of potato and tomato under laboratory and field condition. Inter. J. Agric. Innov. Res., 4 (2): 2319-1473.

A.O.A.C. (1990). "Association of Official Analytical Chemists". Official Methods of Analysis. $15^{\text {th }}$ Ed., Washington, DC, USA.

Bailey, K.L. and Lazarovites, G. (2003): Suppressing soil-borne diseases with residue management and organic amendments. Soil Tillage Res., 72: 169 180.

Beatriz, M.G., Enrique, P. and Aurelio, L.M. (2015). Composition, diffusion, and antifungal activity of black mustard (Brassica nigra) essential oil when applied by direct addition or vapor phase contact. J. Food Prot., 4: 636-858.

Bhattacharyya, P.N. and Jha, D.K. (2012). Plant growth-promoting rhizobacteria (PGPR): emergence in agriculture. World J. Micro. Biotech., 28 (4): 1327-1350.

Cardoso, S.C., Soares, A.C.F., Brito, A.D.S., Laranjeira, F.F., Ledo, C.A.S. and dos Santos, A.P. (2006). Control of tomato bacterial wilt through the incorporation of aerial part of pigeon pea and crotalaria to soil. Summa Phytopathol., 32:27-33. 
Charles, D.J. and Simon, J.E. (1990). Comparison of extraction methods for the rapid determination of essential oil content and composition of basil. $J$. Amer. Soc. Hort. Sci., 3:458-462.

Chialva, F., Gabri, G., Plidde P.A. and Ulian, F. (1982). Qualitative evaluation of aromatic herbs by direct head space (GC2) analysis of essential oils. pp. 183-195. In: M.A. Koedam and D. Vokou (eds). Aromatic Plants: Basic and Applied Aspects. Martinus Nish off, the Netherlands.

Compant, S., Duffy, B., Nowak, J., Clément, C. and Barka, E.A. (2005). Use of plant growth-promoting bacteria for biocontrol of plant diseases: principles, mechanisms of action, and future prospects. Appl. Environ. Micro., 71(9): 4951-4959.

Duncan, D.B.(1955). Multiple rang and multiple F test. Biometrics, 11: 1-42.

Denny, T. (2006). Plant pathogenic Ralstonia species. In: Gnanamanickam, S. S., Plant-associated bacteria. Dordrecht, the Netherlands, Springer. pp 1-62.

El-Fallal, A. A., and Moussa, Z. (2008). Prospects for biocontrol of brown rot disease of potato in vitro and under greenhouse conditions. Plant Path. J., 7: 54-64.

Elphinstone, J.G. (2005). The current bacterial wilt situation: a global overview, p. 9-28. In Allen, C., Prior, P. and Hayward, A.C. (ed.), Bacterial Wilt Disease and the Ralstonia solanacearum species complex. Amer. Phytopathological Soc. Press, St. Paul, MN.

Elphinstone, J.G., Hennessy, J., Wilson, J.K. and Stead, D.E. (1996). Sensitivity of different methods for the detection of Pseudomonas solanacearum in potato tuber extracts. EPPO/OEPP Bulletin, 26:663-678.

El-Zemity, S.R., Radwan, M.A., Mohamad S.A.E.M and Sherby, S.M. (2008). Antibacterial screening of some essential oils, monoterpenoids and novel N-methyl carbamates based on monoterpenoids against Agrobacterium tumefaciens and Erwinia carotovora. Phyto. Plant Prot., 41:451- 461.

EPPO (2004). Ralstonia solanacearum. European and Mediterranean Plant Protection Organization Bulletin, 34: 173-178.

Gamliel, A., Austerweil, M. and Kritzman, G. (2000). Non-chemical approach to soilborne pest management-organic amendments. Crop Prot., 19: 847-853.

Glickmann, E. and Dessaux, Y. (1995). A critical examination of the specificity of the salkowski reagent for indolic compounds produced by phytopathogenic bacteria. Appl. Environ. Micro., 61: 793-796. 
Gómez-Castillo, D., Cruz, E., Iguaz, A., Arroqui, C., and Vírseda, P. (2013). Effects of essential oils on sprout suppression and quality of potato cultivars. Postharvest Biol. Tech., 82: 15-21.

Hammer, K.A., Carson, C.F. and Riley, T.V. (1999). Antimicrobial activity of essential oils and other plant extracts. J. Appl. Microbiol., 86: 985- 990.

Hayward, A.C. (1994). The hosts of Pseudomonas solanacearum. In: Bacterial wilt: the disease and its causative agent, Pseudomonas solanacearum (Ed. by Hayward, A.C.; Hartman, G.L.), pp. 9-24, CAB International, Wallingford, UK.

Holbrook, A.A., Edge, W.J.W. and Bailey, F. (1961). Spectrophotometric Method For Determination Of Gibberellic Acid. In: Gibberellin, A. C. S. Washington, D. C. pp. 159-167.

Hosseinzadeh, S., Bakhsh M.S. and E. Hosseinzadeh E. (2013). Effects of sub-bactericidal concentration of plant essential oils on pathogenicity factors of Ralstonia solanacearum. Phyto. Plant Prot., 46: 643-655.

Hoyerováa, K., Gaudinováa A., Malbecka J., Dobreva P.I., Kocábekb T., Šolcováa B., Trávníčkováa A. and Kamíneka, M. (2006). Efficiency of different methods of extraction and purification of cytokinins. Phytochem., 67 (11): 1151-1159.

Iacobellis, N.S., Lo Cantore, P., Capasso, F., and Senatore, F. (2005). Antibacterial activity of Cuminum cyminum L. and Carum carvi L. essential oils. J. Agric. Food Chem., 53(1): 57-61.

Ji, P., Momol, M.T., Rich, J.R., Olson, S.M. and Jones, J.B. (2007). Development of an integrated approach for managing bacterial wilt and root-knot on tomato under field conditions. Plant Dis., 91:1321-1326.

Kalemba, D. and Kunicka, A. (2003). Antibacterial and antifungal properties of essential oils. Current Medic. Chem., 10: 813-829.

Kelman, A. (1998). One hundred and one years of research on bacterial wilt, p. 1-5. In Prior, P.H., Allen, C and Elphinstone, J. (ed.), Bacterial wilt disease: Molecular and Ecological Aspects. Springer, Heidelberg.

Kempe, J. and Sequeira L. (1983). Biological control of bacterial wilt of potatoes: Attempts to induce resistance by treating tubers with bacteria. Plant Dis., 67 (5): 499-503.

Khalil, Amal, A.H. (2008). Studies on potato brown rot disease in Egypt. Ph.D. Thesis, Fac. Agric., Suez Canal Univ., Egypt, 124 pp. 
Kheirandish, Z. and Harighi, B. (2015). Evaluation of bacterial antagonists of Ralstonia solanacearum, causal agent of bacterial wilt of potato. Biolo. Cont., 86, 14-19.

Kotan, R., Dadasoglu, F. Kordali, S., Cakır, A., Dikbas, N. and Cakmakc, R. (2007). Antibacterial activity of essential oils extracted from some medicinal plants, carvacrol and thymol on Xanthomonas axonopodis pv. vesicatoria (Doidge) Dye causes bacterial spot disease on pepper and tomato. J. Agri. Tech., 3:299-306.

Kotan, R., Dadasoğlu, F., Karagoz, K., Cakir, A., Ozer, H., Kordali, S., and Dikbas, N. (2013). Antibacterial activity of the essential oil and extracts of Satureja hortensis against plant pathogenic bacteria and their potential use as seed disinfectants. Sci. Hort., 153: 34-41.

Kwon, J.W. and Kim, S.D. (2014). Characterization of an antibiotic produced by Bacillus subtilis JW-1 that suppresses Ralstonia solanacearum. J. Micro. Biotech., 24 (1): 13-18.

Li, L., Feng, X., Tang, M., Hao, W., Han, Y., Zhang, G. and Wan, S. (2014). Antibacterial activity of Lansiumamide B to tobacco bacterial wilt (Ralstonia solanacearum). Microbiol. Res., 169:522-526.

Maliak, C.P. and Singh, M.B. (1980). Estimation of total phenols in plant enzymology and histoenzymology. Kalyani Publishers, New Delhi.

Maria, A., Galeazzi, M., Valdemo, C., Garbieri, S. and Spiros, M. (1981). Isolation, purification and physicochemical of polyphenol oxidase (PPO) from a dwarf variety of banana. J. Food Sci., 46 (1): 150-155.

Martin, C., and French, E.R. (1985). Bacterial wilt of potatoes caused by Pseudomonas solanacearum. Technical Information Bulletin 13: 1-6. Centro Internacional de la Papa, Lima, Peru.

Maxwell, D.P. and Bateman, D.F. (1967). Changes in the activities of some oxidases in extracts of Rhizoctonia-infected bean hypocotyl in relation to lesion maturation. Phytopathol., 57: 132.

Momol, T., Ji, P., Jones, J., and Olson, S. (2005). Recommended management strategies for bacterial wilt on tomato caused by Ralstonia solanacearum. NFREC Extension Report, No: 2005-8.

Moussa, Z. (2006). Studies on biological control of brown rot disease of potato. Ph.D. Thesis, Botany Dept, Fac. Sci. at Damietta, Mansoura University, Egypt. 
Nagata, M. and Yamashita, I. (1992). Simple method for simultaneous determination of chlorophyll and carotenoids in tomato fruit. J. Japan Soc. Food Sci. Technol., 39 (10): 925-928.

Nath, B.C., Bora, L.C., Kataki, L., Talukdar, K., Sharma, P., Dutta, J., and Khan, P. (2016). Plant growth promoting microbes, their compatibility analysis and utility in biointensive management of bacterial wilt of tomato. Int. J. Curr. Microbiol. App. Sci., 5(6): 1007-1016.

Noumavo, P.A., Agbodjato, N.A., Baba-Moussa, F., Adjanohoun, A., and Baba-Moussa, L. (2016). Plant growth promoting rhizobacteria: Beneficial effects for healthy and sustainable agriculture. African $J$. Biotech., 15(27):1452-1463.

Okamoto, K, Narayama S, Katsuo A, Shigematsu I, Yanase H. (2002). Biosynthesis of p-anisaldehyde by the white-rot basidiomycete Pleurotus ostreatus. J. Biosci. Bioeng.,93(2): 207-210.

Prabhat A. and Navneet, C.A. (2010). Evaluation of antimicrobial activity of six medicinal plants against dental pathogens. Report and Opinion, 2: 37-42.

Rai, M. K. and Tidke, G. (2005). Biotechnological potential of mushrooms: drugs and dye production. Int. J. Med. Mushrooms, 7: 213

Roy, S., Barman, S., Chakraborty, U. and Chakraborty, B. (2015). Evaluation of spent mushroom substrate as biofertilizer for growth improvement of Capsicum annuum L. J. Appl. Biol. Biotechnol., 3: 22-27.

Seidler-Lożykowska K., Kędzia B., Karpińska E. and Bocianowski J. (2013). Microbiological activity of caraway (Carum carvi L.) essential oil obtained from different origin, Acta Sci. Agr., 35, 495-500.

Singh, G.; Marimuthu, P.; Heluani, C.S. and Catalan (2005). Chemical constituents and antimicrobial and antioxidant potentials of essential oil and acetone extract of Nigella sativa seeds. J. Food Sci. Agric., 85: 2297-2306.

Sonli, A., Karadogan, T., Tonguc, M. and Baydar, H. (2010). Effects of caraway (Carum carvi L.) seed on sprouting of potato (Solanum tuberosum L.) tubers under different temperature conditions. Turkish J. Field Crops, 15 (1): 54-58.

Sood, A. K. and Kumar, P. (2015). Evaluation of essential oils against Ralstonia solanacearum causing bacterial wilt of Solanaceous crops. Plant Dis. Res., 30 (1): 67-72. 
Suzuki, W., Sugawara, M., Miwa, K., and Morikawa, M. (2014). Plant growth-promoting bacterium Acinetobacter calcoaceticus P23 increases the chlorophyll content of the monocot Lemna minor (duckweed) and the dicot Lactuca sativa (lettuce). J. Biosci. Bioengin. ,118(1): 41-44.

Tan, Y.H. and Wahab, M.N. (1997): Extracellular enzymes producing during anamorphic growth in the edible mushroom, Pleurotus sajor-caju. World J. Microbiol. \& Biotechnol., 13: $613-619$.

Terblanche, J. and de Villiers, D.A. (1998). The suppression of Ralstonia solanacearum by marigolds, p. 325-331. In Prior, P.H., Allen, C. and Elphinstone, J. (ed.), Bacterial Wilt Disease: Molecular and Ecological Aspects. Springer, Heidelberg, New York.

Velázquez-Cedeňo, M.A., Mata, G. and Savoie, J. (2002): Waste-reducing cultivation of Pleurotus ostreatus and Pleurotus pulmonarius on coffee pulp: change in the production of some lignocellulytic enzymes. World $J$. Microbiol. \& Biotechnol., 18: 201-207.

Waksman, S.A. (1967). The actinomycetes. The Ronald Press Company, New York, pp. $193-207$.

Wang, H., Wang, J., Xia, H., Huang, Y., Wang, M., Jia, M., and Yu, Z. (2015). Sensitivities of Ralstonia solanacearum to streptomycin, calcium oxide, mancozeb and synthetic fertilizer. Plant Path. J., 14 (1): 13.

Wu, L., Shang, H., Wang, Q., Gu, H., Liu, G., and Yang, S. (2016). Isolation and characterization of antagonistic endophytes from Dendrobium candidum Wall ex Lindl., and the biofertilizing potential of a novel Pseudomonas saponiphila strain. Appl. Soil Ecol., 105: 101-108.

Wu, Z., Yao, L., Kaleem, I., and Li, C. (2012). Application efficacy of biological seed coating agent from combination of PGPR on cotton in the field. In Info. Tech. Agric. Eng. (pp. 903-910). Springer Berlin Heidelberg.

Youssef, S.A. and Tartoura, K.A.H. (2013). Compost enhances plant resistance against the bacterial wilt pathogen Ralstonia solanacearum via up-regulation of ascorbate-glutathione redox cycle. Eur. J. Plant Pathol., 137:821-834.

Yuliar, Nion Y. A. and Toyota, K. (2015). Recent trends in control methods for bacterial wilt diseases caused by Ralstonia solanacearum. Micr. Environ., 30 (1): 1-11. 


\title{
دراسة تأثثير بعض المستحثثات على مرض العفن البني ومحصول الدرنات في البطاطس مرض النف
}

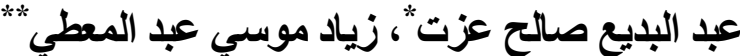

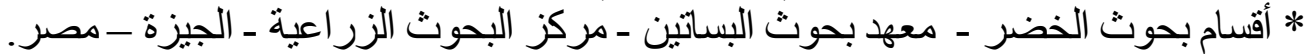 \\ ** قسم الأمر اض البكتيرية ـ معهر بحوث أمر اض النبات ـ مركز البحوث الزئ الزر اعية ـ مصر.
}

بعثبر مرض العفن البني في البطاطس من الأمر اض المنتشرة في جميع أنحاء العالم، ويسبب العبات

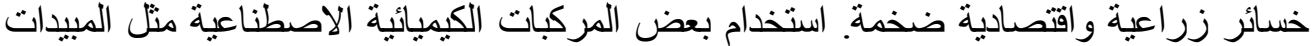

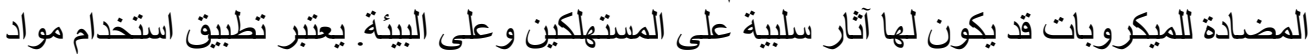

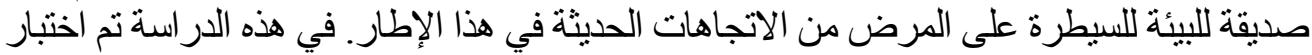

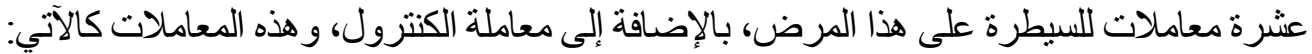

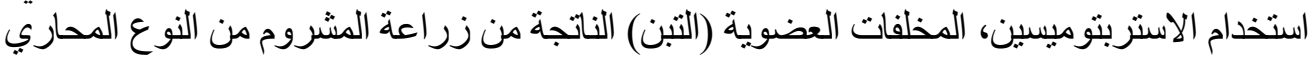

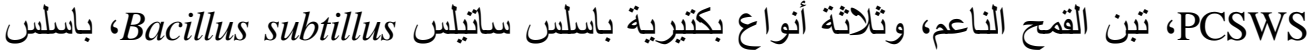

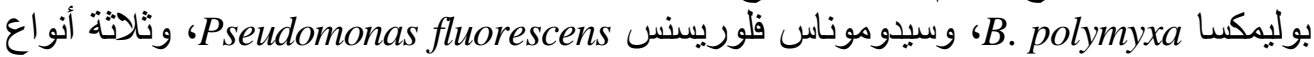

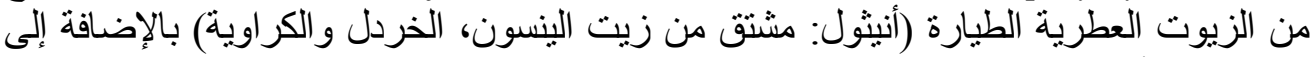

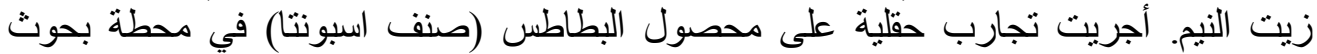

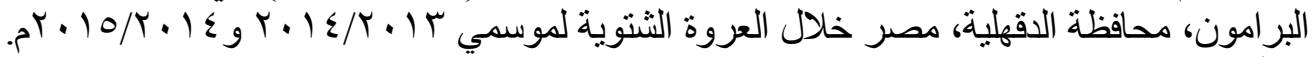

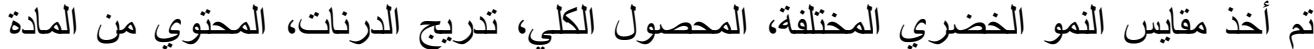
الجافة، الكثافة النو عية للارنات ونسبة الدرنات الندات المصابة.

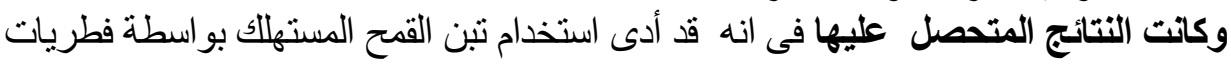

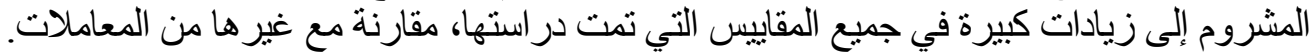

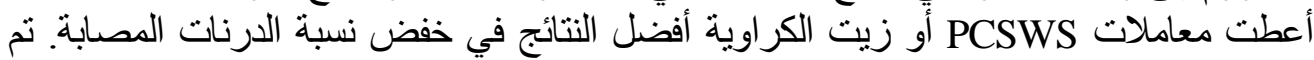

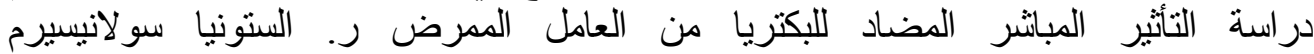

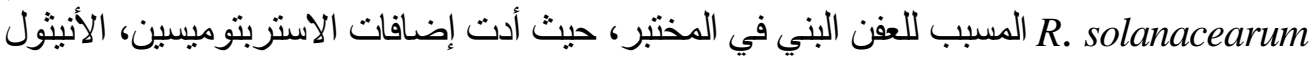

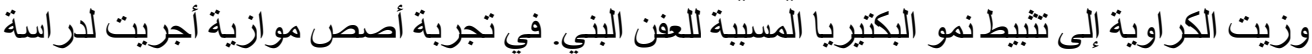

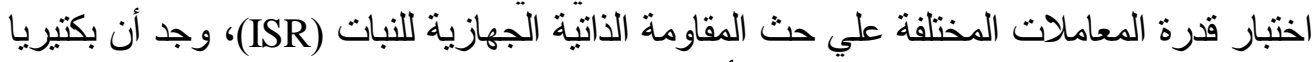
B. polymyxa

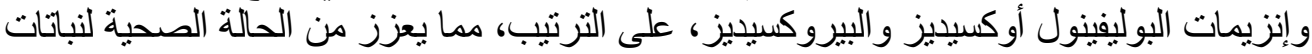

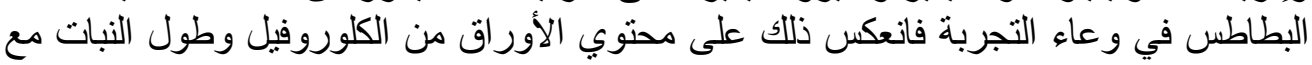

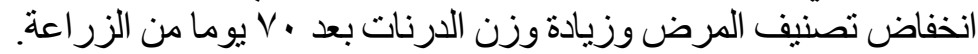

